\title{
Anemari Neple
}

\section{At skrive som Anton Webern}

\section{Intermedial genrehistorie i Tor Ulvens Webernvariationer}

I 1987 publicerede den norske forfatter Tor Ulven (1953-1995) en digtcyklus med

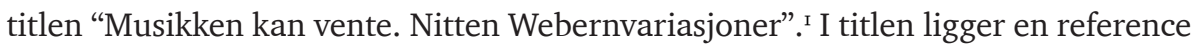
til den østrigske komponist Anton Webern (1883-1945), og det er i lyset af denne reference, at digtene hidtil har været læst. Cyklussen har både været omtalt som en suite til Webern (Larsen 2008, 67) og som en beskrivelse af hans musik (Rege 2004), men ingen har hidtil reflekteret over, at cyklussens undertitel rummer en påstand, som er mere radikal end det. Idet digtene præsenteres som "Webernvariationer", præsenteres de ikke primært som "Weberns variationer" men som Ulvens Webernvariationer. Dette indebærer, at ambitionerne strækker sig ud over både tilegnelsen og ekfrasen. Musikhistorien har talrige eksempler på, at en komponist skriver "variationer" over et tema eller et kortere stykke fra en anden komponist. ${ }^{2}$ Når cyklussens digte får status som "Webernvariationer", skriver de sig altså ind i en genre med lange traditioner i musikhistorien, og signalerer dermed også et genretilhørsforhold til musikken.

Denne artikel er et bidrag til forståelsen af Webernvariationerne og deres genretilhørsforhold, og jeg vil tage udgangspunkt i det, som ved første blik synes at være et paradoks: Til trods for at cyklussen foregiver at være et genreoverskridende værk, er digtene tilsyneladende komfortabelt placeret inden for den modernistiske lyriktradition. Webernvariationerne er strofiske digte på frie vers, og der er i udgangspunktet meget lidt som tyder på, at de skulle have ambitioner om at tage skridtet ud af lyrikken og blive til musik. Alligevel vil jeg hævde, at vi er nødt til at tage cyklussens musikalske genretilhørsforhold alvorligt. Det er afgørende, at vi forsøger at begribe, hvordan Ulven bruger den musikalske variations genretræk i kombination med referencen til Webern, og hvordan referencen i forlængelse af dette fremstår som et råstof for digtenes egen musik. I det følgende vil jeg også argumentere for, at Webernvariationerne kan betragtes som et værk, hvor forskellige, men beslægtede genrehistorier indgår i et samspil med intermediale dimensioner, som i sidste instans udvider vores forestillinger om, hvad musik (og litteratur) kan være. ${ }^{3}$ 


\section{Et genreoverskridende princip}

Som forfatter var Tor Ulven kendt for at arbejde med en mangfoldighed af skønlitterære genrer. Han debuterede med den surrealistiske digtsamling Skyggen av urfuglen i 1977 og udgav flere kritikerroste digtsamlinger i 1980'erne, før han officielt gik over til at skrive prosa. ${ }^{4}$ Men alle de bøger, han udgav, viser en forfatter, som arbejder ud fra et genreoverskridende princip. I digtsamlingerne finder vi ofte en vekslen mellem lyrik, prosalyrik og prosa, og som Janike Kampevold Larsen har bemærket, har også Ulvens strofiske digte som regel en tydelig prosasyntaks (Larsen 2008, 23)..$^{5}$ Tendensen til at ville bryde genregrænserne ned er karakteristisk for den modernistiske tradition, som Ulven tilhører, og den har klare forgreninger til den franske prosadigt-tradition, ikke mindst til René Char (1907-1988), som Ulven også gendigtede. ${ }^{6}$

Udgivelsen af Etterlatte dikt i 1996 viste desuden, at Ulven gerne bearbejdede sine tekster, ofte gentagne gange og over flere år førend han var tilfreds med dem. Også her var genreeksperimenter en vigtig faktor. Et og samme materiale kunne gennemgå en forvandling fra strofisk digt, via stavelsestællende digte, til det endelig fandt sin form som kortprosa-tekst. ${ }^{7}$ Alt dette vidner om, at Ulven gennem hele sit forfatterskab havde et bevidst forhold til genrespørgsmålet og en levende interesse for litterær form.

Udover at eksperimentere i grænselandet mellem poesi og prosa er Tor Ulven også kendt for at udforske grænserne mod andre kunstarter såsom billedkunst og musik. I hans sidste bog, Stein og speil (1995), er alle teksterne præsenteret med en titel, som angiver en genre uden for litteraturen ("Utstilling", "Konsert" osv.). Denne form for erklæret og ofte paradoksal genreoverskridelse fungerer på mange måder i direkte forlængelse af forfatterskabets kernetematik. Både billedkunsten og musikken repræsenterer et fristed hos Ulven - en erfaring af ro, i kontrast til den eksistentielle smerte og angst, som ellers præger forfatterskabet. ${ }^{8}$ At så mange af Ulvens tekster $\varnothing n s k e r$ at tage springet over i en anden kunstart kan altså læses som en intensivering af ønsket om overskridelse i forfatterskabet generelt.

Selv udtalte Ulven, at han ønskede "at kunne skrive som Giacometti, eller som Anton Webern" (Hagen og Hoel), og demonstrerer dermed sin forkærlighed for meditativ minimalisme også i litteraturen. Udtalelsen kunne lige så vel stå som et motto for Webernvariationerne, som synes at strække sig ud mod en musik, som igen strækker sig ud mod stilheden.

\section{En stilhed mellem to klange}

Som medlem af "den anden wienerskole" var Anton Webern, sammen med Arnold Schönberg (1847-1951) og Alban Berg (1805-1935) central i den musikalske nyorientering i første halvdel af forrige århundrede, som skulle lede frem til bruddet med tonaliteten og udviklingen af tolvtonemusikken. Webern var elev af Schönberg fra 1904 til 1908 og er af eftertiden kendt for at anvende tolvtoneteknikken mere kompromisløst end både Schönberg og Berg (Bailey). Hans musik fik stor betydning for flere komponister efter anden verdenskrig, og han regnes som en vigtig inspirationskilde for den såkaldte serialisme, repræsenteret af blandt andre Pierre 
Boulez (1925-) og Karlheinz Stockhausen (1928-2007). I øvrigt er Webern særlig kendt for sin koncentrerede, for ikke at sige knappe stil. Mange af hans værker tager bare få minutter at fremføre, og selv symfonien (Op. 21) kan spilles på knap ti minutter.

I Weberns musikalske univers er virkemidlerne skåret ind til benet. Kompositionerne består gerne af minimalistiske satser med en udstrakt brug af pauser. Melodilinjer og harmoniske progressioner glimrer ved deres fravær, til fordel for komplekse strukturer, rytmiske aspekter og klangfarver. Resultatet er intens koncentration i knap form: En musik som er strippet for al staffage, og hvor stilheden spiller en fremtrædende rolle.

Med dette som udgangspunkt er det ikke vanskeligt at forstå, at Webern bliver et ideal for Tor Ulvens digtning. I kraft af en kompromisløs minimalisme og en særegen evne til at bevæge sig på grænsen af sin egen genre er hans musik et renskåret udtryk for det, som Ulven i sine digte og prosatekster så ofte søger: en kontemplativ erfaring, hvor stilheden får spillerum. Hos Ulven, hvor "mening er smerte" (1996, 134) og bevidstheden repræsenterer "en slags evindelig, aldrig hvilende støj" (1994, 52), er en erfaring af dette format af stor værdi: en begæret, men ofte utopisk tilstand i forfatterskabet i $\varnothing$ vrigt. ${ }^{9}$

Webern er da også en tilbagevendende reference i Ulvens lyrik. I første halvdel af 1980'erne skriver Ulven (foruden Webernvariationerne) flere digte, hvor det at lytte til Webern står centralt, ${ }^{\text {,o }}$ og hvor stilheden fremstår som det bærende element. Følgende digt er dateret 19.2.1984 og blev publiceret i Etterlatte dikt (1996, 40):

4f Jeg lytter

til Webern

for at føle en nyudsprungen

stilhed

mellem to klange, hvor

noget falder

frit

opad

eller nedad

mens håret vokser

Mellem to klange er stilheden "nyudsprungen". Således præsenterer digtet en visualisering af virkemidlerne i Weberns mest karakteristiske instrumentalmusik. Jeg'et i digtet lytter til denne musik for at føle stilheden, der forstærkes på grund af klangene, som omgiver den. Stilheden åbner videre for en følelse af desorientering, hvor det er mulig at føle, hvordan "noget falder / frit / opad eller nedad". Opløsningen er rigtignok både simuleret og kortvarig, men ikke desto mindre kan den her både opsøges og opleves, før digtets næsten prosaiske afslutning bringer os tilbage. 
I stilheden ligger der med andre ord en frihed, som også indebærer frihed fra sprogets og virkelighedens logik. Også dette må siges at være en begæret erfaring hos Ulven, som i sit forfatterskab stadig søger erkendelse hinsides begreberne og drømmer om at fortsætte "forbi ordene, mod den yderste sne og tankeløshed" $(1989,5)$. At lytte til Webern indebærer altså, at jeg'et kan erfare den stilhed, som ellers i forfatterskabet kun kan betragtes på afstand. ${ }^{\text {II }}$

Allerede her synes det klart, at Ulvens fascination af Webern bunder i en opfattelse af, at musikken rummer en indsigt, som man kan lytte til, selv om den ikke nødvendigvis kan formuleres sprogligt. Ulvens ønske om at kunne skrive "som Anton Webern" kan læses som et ønske om at intensivere denne erfaring og formidle den direkte i litteraturen, således at "mening" ikke længere behøver at være forbundet med "smerte".

Alligevel kan netop det at ville skrive som Anton Webern virke som en forgæves ambition. Store dele af Weberns produktion giver i første omgang indtryk af at bestå af mere eller mindre vilkårlige enkeltlyde med lange pauseindslag, langt fra enhver meningssammenhæng. Dette gælder ikke mindst for den del af Weberns kompositioner, som Webernvariationerne knytter an til: Strygerkvartetterne, pianovariationerne og orkestervariationerne. At kompositionerne på denne måde synes at bevæge sig "forbi ordene" gør dem selvfølgelig attraktive i denne sammenhæng. Men kan de overhovedet fanges i ord?

\section{Konventionelle variationer ...}

Med dette som udgangspunkt skulle man tro, at der var lagt op til et omfattende intermedialt genre-eksperiment, når Ulven skriver sine "Webernvariationer". Cyklussens undertitel synes at have en ambition om at præsentere digtene som musik. Samtidig er titlen paradoksal, eftersom den musikalske variation - som cyklussen i så fald knytter an til - hører hjemme i instrumentalmusikken, som jo er en ordløs genre. Titlen repræsenterer dermed også en udfordring, idet den lader til at hævde, at digtene skal kunne læses som instrumentalmusik.

Ved første blik er det imidlertid ikke let at forstå, hvordan denne ambition skulle være realiseret i digtene. Foruden titelbladet består cyklussen af nitten digte, som alle er strofiske digte på frie vers - med andre ord digte, som er typiske for modernismens æstetik. Og selv om de er placeret i en genre "hinsides ordene", fremstår netop ordene som digtenes bærende element. De to indledende variationer er på denne måde karakteristiske:

\section{1}

Anton Webern kommer mod dig

Nej 
foran

lydene af vanddråber

fra en

tænkende

drypstensgrotte. Der går

fem tusind generationer

af fugle

deroppe

mellem hvert

dryp

Den hører

sine egne lyde

forsvinde

i tiden. Du drypper

og bliver borte

II

Musikken lytter

Den har fundet noget

Stumt

(Ulven 1987, 95-97)

Vi skal snart vende tilbage til digtene og deres tilknytning til Webern. Men lad os slå fast, at Tor Ulven, i hvert fald tilsyneladende, ikke giver indtryk af at være specielt eksperimenterende, når han knytter an til Webern i Det tålmodige. Hvad formelle kendetegn angår, lader der ikke til at være meget, som adskiller de to indledende Webernvariationer fra "Jeg lytter / til Webern" i Etterlatte dikt. Med Janike Kampevold Larsen kan vi desuden påpege, at også flere af "variationerne" ser ud til at have en "prosasyntaks" i den forstand, at mange af digtene "ser ud som en hel og fuldstændig sætning, hvis vi fjerner linjedelingen" (Larsen 2008, 23). Hvis Webernvariationernes undertitel giver forventninger om genreoverskridelse, i dette tilfælde mellem litteratur og musik, er dette altså en overskridelse, som synes at være forbeholdt titlen. Målet for cyklussen i øvrigt lader til at være at skrive om Webern, snarere end som ham.

Men til trods for at vi kan argumentere for en "prosasyntaks" også i Webernvariationerne, findes der ingen kendte eksempler på, at Ulven nogensinde forsøgte at 
inkludere Webern-referencer i kortprosaformatet, snarere tværtimod. Referencer til Webern forekommer altid i lyrikken og altid i strofiske digte. ${ }^{\text {I2 }} \mathrm{Og}$ selv om cyklussen i mange tilfælde præsenterer sætninger, som ser ud til at være "hele og fuldstændige", hvis vi fjerner linjedelingen, er netop linjedelingen i dette tilfælde også (som vi snart skal se) et bærende element i cyklussen.

Lad os derfor et øjeblik standse op og spørge, hvorfor den altid formbevidste Ulven konsekvent vælger én udtryksform, når han knytter an til Webern. Hvorfor skriver Ulven sine Webernvariationer som strofiske digte og på frie vers? Hvorfor adlyder han tilsyneladende genrekonventionerne, idet han signalerer, at han agter at overskride dem? For at svare på dette må vi se nærmere på de intermediale og genrehistoriske forbindelser i cyklussen.

\section{Intermedial genrehistorie}

At digte på frie vers kan betragtes som en genrekonvention i dag er i sig selv historisk interessant, eftersom det vidner om, hvordan lyrikken har udviklet sig i det seneste århundrede. Sammen med prosadigtet var det frie vers med til at forny lyrikken som genre fra sidste halvdel af 1800-tallet og fremefter. Strofiske digte på frie vers var også i sin tid med til at rokke ved nogle af de grundlæggende forestillinger om, hvad lyrik er, og mødte af den grund indædt modstand, ikke mindst i Norge. "Poesi er vers; digte uden rim og rytme må der være andre betegnelser for", udtalte den norske digterhøvding Arnulf Øverland i et interview så sent som i 1945 (Rottem 1998, 164). Som Øystein Rottem bemærker, er denne udtalelse "typisk for den måde, det store flertal reagerede på, da en i norsk sammenhæng ny 'modernistisk' lyrik lidt senere gjorde sig gældende efter krigen" (ibid)..$^{\text {13 }}$

Medlemmerne af den anden wienerskole mødte også indædt modstand, da de begyndte at eksperimentere med en ny og indtil da uhørt musik i begyndelsen af 1900-tallet (Grout \& Palisca 1996). På samme måde som lyrikkens brud med faste rim- og rytmemønstre var en udfordring for den traditionsbevidste læser, sendte den nye musiks brud med tonaliteten chokbølger gennem koncertsalene. Modstanden mod den musikalske udvikling, som Schönberg, Berg og Webern repræsenterede, var så stærk, at det i perioder var nødvendigt at fremføre musikken i private foreninger (Bailey), og også i dette tilfælde skyldtes uviljen uenighed i spørgsmålet om, hvad musik var eller kunne være.

Der er altså en genrehistorisk logik i, at Ulven knytter an til Webern via modernistiske digte. Denne logik bliver yderligere klar, når vi ved, at netop lyrikken spillede en central rolle i udviklingen af den form for musik, som Webern blev foregangsmand for (se f.eks. Rege 2004, 15, samt Bailey 2008). Hvis en forfatter ønsker at "skrive som Anton Webern", er det strofiske digt på frie vers med andre ord det ideelle udgangspunkt. I forlængelse heraf kan vi argumentere for, at forholdet mellem lyrik og musik i modernismen tager form af en genrehistorisk intermedialitet, som bliver videreført i Ulvens Webernvariationer.

Webernvariationerne kan dermed også bidrage til en udvidet indsigt i spørgsmålet om forholdet til genrerne i Tor Ulvens forfatterskab generelt: Når Ulven eksperimenterer med genrerne, er dette ikke for eksperimentets skyld, men en del af 
en proces, der handler om at finde en passende form til det meningsindhold, som digtet eller prosateksten søger at formidle. Når målet som her er at nærme sig Weberns musik, anvender Ulven altså det traditionelle, modernistiske digt på frie vers - og eftersom disse genrekonventioner allerede står i mere eller mindre direkte forbindelse til musikken, er der i dette tilfælde ingen grund til at bryde med dem.

\section{Et genreoverskridende værk?}

Indtil videre har vi altså set, at Ulven nærmer sig Webern ved (i udgangspunktet) at adlyde det modernistiske digts genrekonventioner, som engang blev betragtet som grænsesprængende, men som i dag må siges at tilhøre det, Harold Rosenberg har kaldt "the tradition of the new" (jf. Bø-Rygg 1989, 10). Vi har endvidere slået fast, at det nære forhold mellem modernistisk lyrik og udviklingen af den moderne, fritonale musik gør dette valg naturligt. I næste omgang bliver udfordringen altså at forstå, hvorfor og i hvilken grad Webernvariationerne inden for disse rammer alligevel kan betragtes som et genreoverskridende værk.

Jeg nævnte tidligere, at de to indledende Webernvariationer har flere træk til fælles med digtet “Jeg lytter / til Webern" fra 1984. Som vi ser, har også digtene fra cyklussen klare referencer til Webern, og de kan (som titlen indikerer) læses som "variationer" over de samme elementer i musikken, som blev tematiseret i Etterlatte dikt: stilheden mellem to klange. Vi skal imidlertid bemærke, at de to variationer ved nærmere eftersyn behandler disse elementer i et andet og markant anderledes perspektiv.

Her findes ikke længere et jeg, som lytter til Webern. Første Webernvariation opretter i stedet en direkte forbindelse mellem Webern og "dig" ved at etablere en scene, hvor begge optræder som aktører. Indledningsvis præsenterer cyklussen tilsyneladende ikke Weberns musik, men komponisten personligt. Dette negeres i anden strofe, som kun består af et "Nej", grafisk udhævet med stort bogstav og mellemrum både før og efter. Her bliver opstillingen i første strofe altså tilbagekaldt, og tredje strofe tager form af en nuancering: "han har sendt lydene foran". Digtet identificerer lydene som "vanddråber / fra en // tænkende // drypstensgrotte", og præsenterer med dette den "grotte" som også er cyklussens bærende motiviske rammeværk. Derefter anslås det, hvor lang tid der går "mellem hvert / dryp", noget grotten selv er i stand til at reflektere over. Digtets "du" er afslutningsvist selv en del af dette univers og evner at foretage den samme operation som vanddråberne.

Anden Webernvariation er af en anden karakter og består af to strofer koncentreret omkring et billede: musikken som lytter til (sin egen) pause. Vi bemærker, at musikken, i lighed med grotten, er udstyret med menneskelige egenskaber. Brugen af prosopopeia skaber dermed en forbindelse mellem de to elementer: grotten tænker, musikken lytter. Grotten hører lydene, musikken finder det stumme. Allerede her ser vi, hvordan Webernvariationerne smelter forskellige elementer sammen: Det visuelle og poetiske niveau på den ene side. Det auditive og musikalske niveau på den anden. 


\section{Et værk i udvikling}

Snarere end at lytte til en allerede eksisterende komposition har vi i disse digte indtryk af at være vidne til et værk i udvikling. Med andre ord fremstår cyklussen som en arena, hvor centrale elementer fra Weberns musik kan virke aktivt. For det første bemærker vi, hvordan cyklussen knytter an til en helt speciel motivkreds for at anskueliggøre musikken. Hvor vi i Etterlatte dikt stod over for en "stilhed / mellem to klange" (1996, 40), hører vi denne gang lydene af "vanddråber / fra en // tænkende // drypstensgrotte" (1987, 95). Effekten er, på dette stadie, både beskrivende og fortolkende. På den ene side fungerer motiverne analogt i forhold til musikken. Samtidig placerer de, som Geir Rege påpeger, musikken "i en helt anden kontekst end alt hvad man er vant til fra Webernlitteraturen" (Rege 2004, 4).

For det andet bliver vi klar over, at digtene også rytmisk evner at knytte an til musikken. Vekslingen mellem ord og pauser er i Webernvariationerne komponeret på en sådan måde, at læseren efterfølgende vil kunne genkende det musikalske forlæg - også selv om han eller hun som udgangspunkt er ubekendt med Webern. ${ }^{14}$ Digtene demonstrerer dermed de intermediale relationer mellem lyrikken og musikken i modernismen. Samtidig fremstår de frie vers i cyklussen i dette perspektiv som mere "bundne" end ellers. Til forskel fra metriske vers anses frie vers gerne for at være "motiverede af sprogstoffets organisering alene" (Lothe, Refsum og Solberg 1997, 85). Dette må imidlertid nuanceres i forhold til Webernvariationerne, hvor versenes organisering også er motiveret af musikkens referentielle komponenter.

\section{Ekspansive pauser}

En række af de bærende motiver i digtene (vanddråberne, mellemrummene, tidsoplevelsen, musikken og pausen) er sammen med den rytmiske organisering dermed egnede til at belyse karakteristiske kendetegn ved Weberns kompositioner, som den tidligere receptionen også har bemærket (Larsen 2008, Rege 2004, Andersen 2005). Men digtene går samtidig ud over det beskrivende niveau. Et godt eksempel er åbningsdigtets angivelse af tiden mellem lydene af vanddråberne i grotten: "Der går / fem tusind generationer /af fugle / deroppe // mellem hvert / dryp" (Ulven 1987, 95).

Tidsangivelsen er her tilsyneladende eksakt men i realiteten utilgængelig. Læseren har ingen mulighed for at omsætte "fem tusind generationer / af fugle" til dage, måneder eller år. (Digtet specificerer heller ikke, hvor lang tid én generation eventuelt omfatter i fugleperspektiv). Alligevel mærker vi os følgende: Hvis tidsangivelsen fungerer som et billede på en musikalsk pause, skildrer digtet en pause som aldrig vil kunne gengives i en koncertsal. Dette følges op i de øvrige digte i cyklussen: Pausen er henholdsvis "stor // og ubeboet" (variation VI, Ulven 1987, 101), den "vokser // omkring os" (variation XIV, 109), og den varer længe nok til, at "[1]angt, sejt græs" gror op (variation X, 105). I variation III er den lang nok til, at hele orkesteret "når at dø" (98). Med tanke på at selv en udstrakt musikalsk pause i læserens fænomenverden bare vil kunne vare nogle sekunder, er dette bemærkelsesværdigt. Hvis digtene henter inspiration fra Anton Webern, strækker de med andre ord virkemidlerne til det yderste. 


\section{Variationens virtuositet}

I dette perspektiv er det naturligt at stille spørgsmålet, om digtenes tilnærmelse til Webern på ny og digtenes status som variationer fremstår med fornyet aktualitet. Som musikhistorisk genre har "variationen" rødder i den klassiske instrumentalmusik, hvor den kan spores tilbage til 1500-tallet. Et typisk værk består gerne af et tema (det kan være en melodilinje, en harmonisk progression etc.), som danner udgangspunkt for en serie variationssatser. Som oftest kan vi observere både forenklede og mere virtuose satser inden for en serie, som gør brug af forskelle i temperament, tempo, udstrækning og lignende.

Når Webernvariationerne placerer sig i denne genre, betyder det i første omgang, at det referentielle rammeværk udvides. Det samme gør vores forventninger om, hvilken slags forbindelse cyklussen skal etablere til Weberns musik. Det musikalske variationsværk er i sin natur referentielt, men repræsenterer samtidig altid mere end én beskrivelse eller en fortolkning. Det oprindelige tema definerer rammerne for variationsrækken, men det står samtidig den enkelte komponist frit for at udforske og udfordre disse rammer. Her findes der med andre ord intet krav om at være tro mod udgangspunktet. Snarere er det nærmest et genreprincip, at fortolkningen bliver radikal. ${ }^{15}$

Særligt interessant i denne sammenhæng er det, at variationsformen giver anledning til at $d v æ l e$ og dermed også til at uddybe og forstærke en pointe (Sisman). På mange måder er det netop denne mulighed, Webernvariationerne griber. Digtene i cyklussen tager udgangspunkt i et centralt kendetegn ved Weberns musik: evnen til at fremhæve den musikalske pause. Dette aspekt ved musikken bliver derefter genstand for en ekspansiv videreføring i digtene. Dels sker dette ved indskrivningen af den tænkende drypstensgrotte som cyklussens motiviske rammeværk. Dels sker det i form af kontemplativ refleksion i cyklussens andet digt. Og endelig har vi de metaforiske tidsangivelser som angiver pauserne i generationer af henholdsvis fugle (i første variation) og orkestermedlemmer (i tredje variation). I alle tilfælde kan vi observere, hvordan digtene arbejder for at strække pauserne ud over det, et menneskeligt øre kan fatte, og ud over det, nogen musiker er i stand til at spille. Effekten er slående: Det er, som om Weberns kompositioner udgør et mikrokosmos i cyklussens makrokosmos.

\section{Imaginær musik}

Webernvariationerne kombinerer altså elementer fra modernistisk lyrik og musik og "varierer" dem med det resultat, at dimensionerne i pauserne forstørres ud over det, som kan erfares i læserens verden. I første omgang er disse forstørrede dimensioner sprogligt tilgængelige via metaforer og sammenligninger. Men ser vi nærmere på digtene, har de også indvirkning på, hvordan vi erfarer digtenes (og i næste instans musikkens) rytme, ved at de trækker opmærksomheden mod de blanke linjer mellem stroferne og udvider oplevelsen af dem. Når man siden lytter til Webern, kan man opleve, at også pauserne i musikken føles større end før, og musikkens pauser (i sekunder) bliver som et ekko af cyklussens pauser (i generationer). Det er, som om vi her får tilgang til en form for visuel musik, idet vi tilegner os pauser, 
som kun er mulige som poetiske forestillinger. Dette resulterer igen i et spændingsforhold mellem rytmen i musikken på den ene side, rytmen i digtene på den anden side og endelig den rytme, som er beskrevet i digtene. På denne måde forenes lyrikken og musikken i Webernvariationerne, ved at de har stilheden til fælles. ${ }^{16}$

Her kommer endelig også Webernvariationernes genreparadoks til sin ret: Ved at erklære sig som (instrumental)musik skriver cyklussen et musikalsk meta-niveau ind i digtene og inviterer læseren til at reflektere over, at cyklussen "spiller" en musik, som ikke kan høres eller ses - men som alligevel er tilgængelig på et imaginært niveau. I kraft af digtenes referentielle forankring i Weberns musik og deres evne til at udnytte lyrikkens iboende musikalske virkemidler bliver dette niveau et spørgsmål om noget mere end et paradoks på påstandsniveau. Resultatet er, at Webernvariationerne fremstår som et sjældent vellykket eksempel på musikalsk-lyrisk interaktion. Digtene udstrækker mulighederne for sproglig repræsentation af musik, samtidig med at det lykkedes for dem at realisere en stilhed, som ikke kan opleves af nogen, men som kan erfares i digtene, med referentiel forankring i Weberns musik.

\section{Afslutning}

Når Ulven nærmer sig Webern, er det altså ikke for at udforske hverken tolvtonerækker, treklange eller harmoniske progressioner. Webernvariationerne samler sig i stedet om stilheden. Dette perspektiv er tydeligt allerede i hovedtitlen, "Musikken kan vente", som både kan læses som et billede på den musikalske pause og som et udtryk for stilhedens betydning, både i Ulvens musikforståelse og i Weberns musik. Ulvens ambition om at skrive "som Anton Webern" handler dermed måske ikke så meget om at skrive toner som om at skrive pauser. Og Webernvariationerne realiserer, som vi har set, denne ambition ved at kombinere genretræk fra modernistisk lyrik og musik og spille dem ud som "variationer".

Som vi har set, kan cyklussen også læses som en intermedial genrehistorie i kraft af, at den evner at demonstrere de tætte bånd mellem moderne lyrik og musik. Ved at erklære sig som musik udforsker Webernvariationerne sine egne grænser. Men de står samtidig i forbindelse med en musik, som udforsker sin grænse. Og ved at forene sine kræfter med musikkens åbner digtene for et samspil mellem genrerne, hvor læseren får adgang til en meditativ stilhed af både lyriske og musikalske dimensioner.

Oversat fra norsk af Sara Tanderup

\section{Noter}

I Cyklussen blev første gang publiceret i Det tålmodige (Ulven 1987, 93-114). Tegnsætning følger originalen. Herefter henvist til som Webernvariationene. Et udvalg af digtene er oversat til dansk af Peter Nielsen (Ulven 1991, 48-53). Alle digte i denne artikel er oversat af Sara Tanderup.

2 Berømte eksempler inkluderer Beethovens "Diabelli-variationer", Brahms' "Variationer over et tema af Haydn" og Rachmaninovs "Rapsodi over et tema af Paganini". For en omfattende introduktion til musikalske "variationer" og deres plads i musikhistorien, henviser jeg til Elaine 
Sismans artikel "Variations" i det anerkendte opslagsværk New Grove Dictionary of Music and Musicians.

3 Af hensyn til artiklens omfang vil det her ikke blive muligt at behandle cyklussen i dens fulde bredde. Det er derfor værd at bemærke, at de nitten Webernvariationer udgør et forløb, som udspiller sig i en "tænkende drypstensgrotte" (Ulven 1987, 85) og kombinerer historiske motiver og naturmotiver (såsom kalkvand) med beskrivelser af musikalske elementer (som klangeffekter og instrumenter). Alt dette smelter i cyklussen sammen til en helhed, hvor nutid forbindes med urtid, og kunstmusik skrives ind i naturen - og omvendt. Foruden den generelle reference til Webern rummer nogle af digtene også enkelte værkreferencer, blandt andet til pianovariationerne (Op. 27, Variation IV). Det mest centrale virkemiddel i cyklussen er imidlertid utvivlsomt den musikalske pause, og det er i udforskningen af pausen, at cyklussen for alvor viser sig som et genreoverskridende værk.

4 I et interview til tidsskriftet Vagant beskriver Ulven selv overgangen fra lyrik til prosa som resultatet af et eksperiment: "Jeg fik efterhånden følelsen af at have skrevet mig ind i et hjørne. [...] Og da er der selvsagt noget galt. Jeg begyndte at eksperimentere med mere fyldige digte og opdagede bagefter, at de var kamufleret prosa. Siden har jeg omarbejdet dem til kortprosa. Det store spørgsmål blev så: kunne jeg skrive prosa? En sommer gjorde jeg et forsøg, og resultatet blev Gravgaver. Siden da er det blevet til prosa" (Hagen og Hoel).

5 Janike Kampevold Larsen (2008) skriver mere om genreglidningen i forfatterskabet i sin bog $\AA$ være vann $i$ vannet. Forestilling og virkelighet $i$ Tor Ulvens forfatterskap. Se især ss. 17-72. Foruden strofiske digte og kortprosa favner Ulvens forfatterskab blandt andet "aforistiske tekster og maksimer”, tekster i novellelængde (såkaldte "historier”) og en roman. Nævnes må også Ulvens første prosabog, Gravgaver (1988), med undertitlen "Fragmentarium", som er blevet sammenlignet med en punktroman.

6 For en mere udførlig redegørelse for dette henviser jeg til Marit Grøttas bog Litterære bagateller (2009, 164-171). Tor Ulvens gendigtning af René Char (Raseri og mysterium, dikt og aforismer i utvalg) udkom på Gyldendal norsk forlag i 1985. Om forholdet mellem Ulven og Char se især Jørn Erslev Andersens artikel "Fragmentariske memorabilia. Ulven, Char og Lascaux" (2003).

7 Henning Hagerup redegør for dette med illustrerende eksempler i sit efterord til Ulvens Etterlatte dikt (1996).

8 Se Lone Hartmanns Sproglige stilleben (2007) for en indsigtsfuld refleksion over, hvordan dette gør sig gældende i Ulvens kortprosa, med særlig vægt på stillebenmotiverne.

9 Jeg skriver mere udførligt om denne tematik i Ulvens forfatterskab i min masteropgave "Anskuelsens akvarium. Erkjennelsesproblematikk og grenseerkjennelse i Tor Ulvens sene prosa, med vekt på fire historier fra Vente og ikke se" (2006).

Io Ulven 1996, 33 og 40. Digtene er daterede henholdsvis 18.11-3.12.1983 og 19.2.1984.

II I historien "Havet" fra Vente og ikke se reflekterer fortælleren for eksempel over, at der "i stenene og planterne [findes] en stilhed som i grunden er ufattelig, en stilhed som er desto større eftersom den ikke kan opleves af nogen" (Ulven 1994, 52).

I2 Til sammenligning refererer Ulven til Johannes Brahms (1833-1897) både i digte (1996, 28), i kortprosa $(1995,93)$ og i et længere prosafragment (1988, 5-9).

I3 Også i analyseterminologien kan vi spore en vis ambivalens i tilnærmelsen til frie vers i Norge. Atle Kittang og Asbjørn Aarseth præciserer i deres bog Lyriske strukturer, som blev udgivet første gang i 1968, at de bruger begrebet "i symbolistenes betydning, nemlig om vers som ikke er bundet til noget fast metrisk skema" (Kittang \& Aarseth 1998, 315), før de tilføjer at: "Mange, bl.a. 
Hallvard Lie i sin Norsk verslære bruger frie vers om metriske vers af forskellig længde, og vælger at betegne symbolistenes vers libre som frie rytmer. Denne betegnelse mener vi, er uheldig af flere grunde, men først og fremmest fordi den ikke kan gøre rede for forskellen mellem prosalyrik og 'vers uden rim og rytme"' (ibid).

I4 Hadle Oftedal Andersen er inde på dette i sin artikel fra 2005.

I5 Ludwig van Beethovens (1770-1827) "Diabelli-variationer" fra 1883 (Op. 120) er et godt eksempel på dette. Med udgangspunkt i en enkel vals af Antonio Diabelli (1781-1858), viser Beethoven i sin variationsrække en enestående vilje til at udtømme udgangspunktet, strække grænserne for det oprindelige rammeværk og herigennem skabe et monumentalt og overskridende værk. Dette sker samtidig med, at hver af de 33 variationer tilkendegiver deres slægtskab med den enkle vals, som de udspringer af. I lighed med flere af Beethovens sene kompositioner bliver Diabellivariationerne på denne måde et kontemplativt, selvfortolkende værk ligeså meget som, eller mere end, en fortolkning af originalen. Ulvens bearbejdelse af Webern har, som jeg forsøger at vise i denne artikel, visse lighedstræk med Beethovens tilnærmelse til Diabelli: dels fortolkende og referentiel, dels videreførende og virtuos, og med et klart kontemplativt præg.

I6 Det er værd at bemærke, at vi her ser en anden side af Ulvens lyrik end den "kølige", "dissekerende" side, som ofte bliver fremhævet i sekundærlitteraturen (se f.eks. Larsen 2003, 27). Webernvariationerne viser efter min mening, at der også i Ulvens lyriske forfatterskab findes en kontemplativ dimension, med paralleller til kortprosaen, således som Lone Hartmann analyserer den (2007).

\section{Litteratur}

Andersen, Hadle Oftedal (2005): "Musikken i grotta. Om tilhøvet mellom det rytmiske og visuelle i Tor Ulvens lyrikk" i Sissel Furuseth (red.): Kunstens rytmer i tid og rom. Trondheim: Tapir Akademisk Forlag, s. 301-314.

Andersen, Jørn Erslev (2003): "Fragmentariske memorabilia. Ulven, Char og Lascaux" i Ole Karlsen (red.): Steinens hvorfor er ditt hvorfor. Om Tor Ulvens forfatterskap. Oslo: Unipub, s. 125-133.

Bailey, Kathryn: "Webern, Anton”, i Grove Music Online, http://www.oxfordmusiconline.com:80/ subscriber/article/grove/music/29993, (09.09.2008.).

Bø-Rygg, Arnfinn (1989): Modernismens estetikk. Bergen: Filosofisk institutt, Universitetet i Bergen. Grout, Donald Jay og Claude V. Palisca (1996): A History of Western Music, femte udgave. New York/ London: W. W. Norton \& Company.

Grøtta, Marit (2009): Litterære bagateller. Introduksjon til litteraturens korttekster. Oslo: Cappelen. Hagen, Alf van der og Cecilie Schram Hoel: "Et språk som gløder, men later som det ligger under kaldt, ildfast glass" Interview med Tor Ulven. Første gang publiceret i Vagant 4/93.” Elektronisk tilgængelig: http://www.vagant.no/et-sprak-som-gloder-men-som-later-som-om-det-ligger-underkaldt-ildfast-glass/ (24.08.2014).

Hartmann, Lone (2007): Sproglige stilleben. En læsestrategi til Tor Ulvens kortprosa. Odense: Syddansk Universitetsforlag.

Kittang, Atle og Asbjørn Aarseth (1998): Lyriske strukturer. Innføring i diktanalyse. 4. utg. Oslo: Universitetsforlaget.

Larsen, Janike Kampevold (2008): Å være vann i vannet. Forestilling og virkelighet $i$ Tor Ulvens forfatterskap. Oslo: Gyldendal. 
for er ditt hvorfor. Om Tor Ulvens forfatterskap. Oslo: Unipub, s. 17-36.

Lothe, Jacob, Christian Refsum og Unni Solberg (1997): Litteraturvitenskapelig leksikon. Oslo: Kunnskapsforlaget.

Neple, Anemari (2006): Anskuelsens akvarium. Erkjennelsesproblematikk og grenseerkjennelse i Tor Ulvens sene prosa, med vekt på fire historier fra Vente og ikke se. Upubliceret mastergradsafhandling. Bergen: Universitetet i Bergen.

Rege, Geir (2004): 'Wie ein Hauch'. Lytteerfaring med Anton Weberns musikk. Upubliceret hovedfagsafhandling. Oslo: Universitetet i Oslo.

Rottem, Øystein (1998): Vår egen tid 1980-98, bind 3, Rottem: Etterkrigslitteraturen. Oslo: Cappelen. Sisman, Elaine: "Variations" i Grove Music Online, http://www.oxfordmusiconline.com/subscriber/ article/grove/music/29050 (16.10.2011).

Ulven, Tor (1987): Det tålmodige. Dikt. Oslo: Gyldendal.

Ulven, Tor (1988): Gravgaver. Fragmentarium. Oslo: Gyldendal.

Ulven, Tor (1989): Søppelsolen. Memorabilia. Oslo: Gyldendal.

Ulven, Tor (1991): Endnu varm. Digte. Oversat af Peter Nielsen. Aarhus: Husets Forlag.

Ulven, Tor (1994): Vente og ikke se. Historier. Oslo: Gyldendal.

Ulven, Tor (1995): Stein og speil. Mixtum Compositum. Oslo: Gyldendal.

Ulven, Tor (1996): Etterlatte dikt. Redigeret af Henning Hagerup og Morten Moi. Oslo: Gyldendal. 